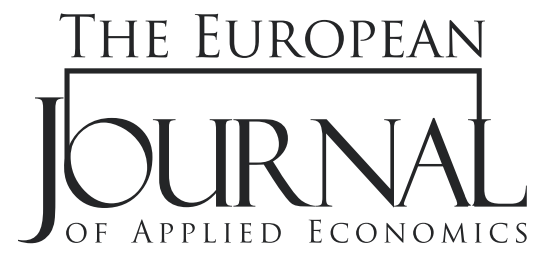

EJAE 2018, 15(2): 29-42

ISSN 2406-2588

UDK: 658.286.4:502/504(669)"1984/2014"

005.591 .1

DOI: 10.5937/EJAE15-17360

Original paper/Originalni naučni rad

\title{
TRADE, TRANSPORTATION AND ENVIRONMENT NEXUS IN NIGERIA
}

\author{
Adedayo Emmanuel Longe ${ }^{1, *}$, Kayode Daniel Ajulo, Olawunmi Omitogun², Emmanuel Olajide Adebayo ${ }^{3}$ \\ ${ }^{1}$ Center for Petroleum, Energy Economics and Law, University of Ibadan, \\ Ibadan, Oyo State, Nigeria \\ ${ }^{2}$ Department of Economics, Olabisi Onabanjo University, \\ Ago-Iwoye, Ogun State, Nigeria \\ ${ }^{3}$ Department of Economics, Bowen University, \\ Iwo, Osun State, Nigeria
}

\begin{abstract}
:
This study investigates trade, transportation and environment nexus in Nigeria. The main objective of the study is to incorporate transportation activities and trade into the EKC model seeing transportation as an important factor that determines environmental degradation in Nigeria. Annual data from 1984 to 2014 is used in the study, whereas ARDL estimation technique was adopted to analyse the data. The results show that all the variables have a positive significant correlation with carbon emissions in Nigeria except trade that was negative and insignificant. According to ARDL estimates, trade, import transport services and GDP per capita have positive impact on CO2 emissions in the long-run while in the short-run, the result shows that trade, GDP per capita, energy consumption and transport services are capable of correcting about $74 \%$ deviation of carbon emissions back to long-run equilibrium. Based on the findings, drawn conclusion stipulates that energy consumption and trade are the main determinant factors that contribute to carbon emission and appropriate attention should be given to energy consumption by considering alternative efficient energy sources to curb the increasing emission in Nigeria.
\end{abstract}

\section{Article info:}

Received: May 8, 2018

Correction: May 28, 2018

Accepted: June 1, 2018

\section{INTRODUCTION}

The impact of ozone layers depletion has been a matter of great concern in recent years. Many factors are considered to contribute significantly to environmental degradation, but economic activities and energy consumption are recognized as the initiators of the phenomenon (Avetisyan et al. 2010). The increase in economic activities was traced to high influx of people to the urban centers as a result of more opportunities available in the cities (Achike et al. 2012). The migration act positively contributes 
to the number of vehicles in the urban centers which results in traffic congestion, as transport services experienced a positive change in developing countries such as Nigeria where it occurs (Fenger, 2009).

Studies on the trade, transport and environmental degradation are mixed as they are mostly considered separately. Among the studies on the nexus between trade and environmental degradation, Islam, Cheng and Rajib (2012); Ahmad and Wyckoff (2013); Kozul-Wright and Fortunato (2012); Keho (2016); Ali, Zaman and Ali (2015); and Fernandez-Amador, Francois, \& Tomberger (2016) support theoretical assumption that trade activities increase carbon emissions. On the other hand, Hasson and Masih (2017), and Athula (2011) argued against the assertion that in the long-run, there is a high probability that trade will reduce carbon emissions through the use of improved technology in the transport sector. This, however, proves that transport is an important determinant of environmental degradation, and confirms the assumptions of Xie, Fang and Liu (2017); Wang, Xie and Yang (2016) who claimed that transportation activities significantly contribute to carbon emissions, out of which most emissions are from trucks (Konur and Schaefer, 2014).

In Nigeria, the use of fossil fuel is common in the transportation sector, being the major source of the transport sector power. It was also documented that a larger percentage of the imported oil products are consumed in the transport sector through trade activities (Achike et al. 2012). As well as other developing countries, Nigeria was also found to be a country that consumes more finished goods, and exports less (Achike et al. 2012). This, however, implies that both import and export activities in the country contribute more to environmental degradation. As documented by World Bank (2017), transport services in the Nigerian economy contribute more to environmental degradation than trade activities. Between 1977 and 1987, the percentage of trade to GDP, percentage of transport services to commercial export and import services and carbon emissions were recorded to be $41.65 \%, 16.91 \%$, 41.09\% and 41.07\% respectively. Between 1988 and 1997, trade and carbon emissions increased to $76.86 \%$ and $52.96 \%$ respectively, while transport services from export and import increased to $11.55 \%$ and $15.86 \%$. As trade experienced a fall between 1998 and 2007 to $64.46 \%$, carbon emission also reported a fall to $44.05 \%$, while transport service through export and import increased to $75.59 \%$ and $32.16 \%$ respectively. In 2014, it was recorded that trade and carbon emission decreased further to $30.89 \%$ and $35.89 \%$, while transport services in the export sector increased to $51.37 \%$ and from the import sector increased to $37.89 \%$ (WDI, 2017). This implies that the correlation between trade and carbon emissions is high, while it's lower between transport services and carbon emissions (See figure 1). On this note, it is important to investigate the relationship between trade, transportation services and the environment in the context of Nigeria.

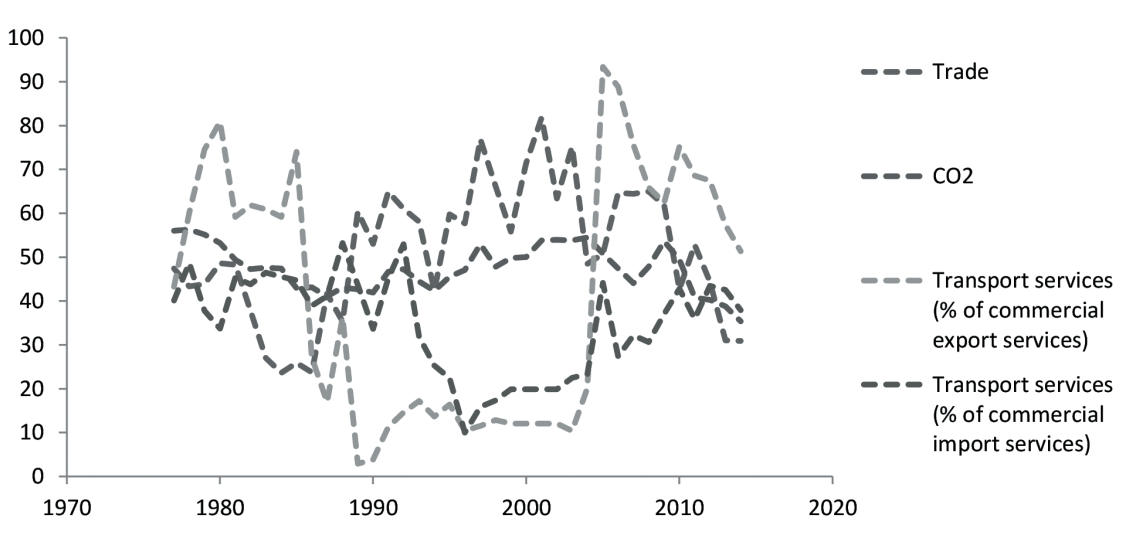

Figure 1. Trend Analysis of Trade, $\mathrm{CO} 2$ and Transport Services

Source: Authors, (2018) 
The rest of the study is partitioned into four parts; section two give details on the literature review, section three presents the data source and model specification, section four reveals the analytical framework, while section five entails the conclusion and recommendation(s).

\section{LITERATURE REVIEW}

Theoretically, argument on the factors responsible for increased environmental degradation is noted through the submissions of Environmental Kuznets Curve (1955), Environmental Daly Curve Hypothesis (1973), and Brundtland Curve Hypothesis (WCED 1978) and has grabbed the attention of researchers on the phenomenon in developed and developing countries. Empirically, Avetisyan et al. (2010) incorporated global data on trade, transportation models, transport emissions, and output emissions in North-America and noted that $90 \%$ of global trade related emissions in machinery exports are due to international transportation. Similarly, Cristea et al. (2013) using U.S. database observed that trade contributes less to emission compared to the amount of emissions from transportation. Using a mathematical model to analyze the relationship between international trade and carbon emissions in Bangladesh; Islam et al. (2012) argued that the trade activities in Bangladesh significantly contribute to emissions.

By adopting conservative approach to investigate carbon emissons embodied in international trade of good in OECD countries; Ahmad and Wyckoff (2013) noted that the amount of carbon emissions embodied in gross flow of imports and exports is relatively significant. Giving instances, the study revealed that the emissions embodied in imports and exports of Sweeden's economy amounts to 50\% of its total domestic production of emissions, while the emission embodied in imports to the United States represents $2.5 \%$ of the global carbon emissions from fossil fuel combustion. In China, Feng et al. (2013) examined carbon emissions and export trade nexus in China using input-output model. The study verified that larger proportion of emissions in the economy are from export trade activities such as textile, chemicals and plastic products among others. Similarly in the U.S. economy, Weber et al. (2007) investigated the import trade, transportation and carbon emissions nexus using a multiregional input-output analysis. The study confirmed that the supply chain of importation, transport and retail activities positively relates to carbon emissions. The study suggested two approaches which are: environmental supply chain management by industrial sectors, and international rationalization of environmental policy by the government.

Using STIRPAT model to incorporate the effect of transportation infrastructure on urban carbon emissions in China; Xie et al. (2017) discovered that construction of transportation infrastructure, population size, per capita GDP, energy intensity, and industrial structure contribute to rises in urban carbon emissions and intensity. In clarifying this, they further revealed that in large-scale cities, construction of transport infrastructure positively affect urban carbon emissions and intensity and it is the same for medium cities, while for small scale cities their impact is insignificant. Wang et al. (2016) ascertained from their findings for the economy of Jiangsu that growth in GDP and transportation contribute masively to the increase in carbon emissions. Integrating inventory control and transportation decisions under carbon emissions regulatios, Konur and Schaefer (2014) discovered that emission generated from vehicles (trucks) forms majority of the emissions from the transportation sector. Takarada et al. (2014) used two model general equilibrium model to analyse international transport sector and welfare nexus. It was noted that there was a unilateral reduction in the number of pollution permit from international transport sector and individual welfare. 
Also, Kozul-Wright and Fortunato (2012) studied the relationship between international trade and carbon emissions. They presented that a positive relationship exists between trade and emssions in the developed countries and likewise for the less industrialised countries. Keho (2016) determined the effect of trade openness on environmental among eleven (11) ECOWAS countries using co-integration bounds test and granger causality. The study detected a positve longrun relationship between carbon emissions and trade, and a bi-directional long-run causality running from pollution to economc expansion in four (4) ECOWAS countries. This is attributable to energy use by high-polluting industries, and importation of used car. In Pakistan, Ali, Zaman and Ali (2015) also confirmed that trade openness which is a result of foreign direct investment inflow, causes environmental degradation through old technogies. While in South Africa, Hasson and Masih (2017) used ARDL approach to investigate the relationship between energy consumption, trade openness, economic growth, carbon emissions, and electricity consumption. The study revealed that there is a cointegrating relationship between energy consumption, trade openness, economic growth, carbon emissions, and electricity consumption. The study argued that in the longrun, higher level of trade openness reduces carbon emissions via the promotion of environmental technology development that brings about less pollution and energy efficiency. In Sri Lanka, Athula (2011) argued that there is no longrun causality between trade openness and carbon emissions, but a uni-directional causality running from trade to carbon emissions was identified in the short-run. This implies that an increase in trade will cause carbon emissions to rise in the short-run.

Fernandez-Amador et al. (2016) examined the relationship between carbon dioxide emissions and international trade. The study identified a link between global supply and demand of goods and services, international trade, and carbon emissions. Investigating the effect of carbon footprints, fuel subsidies and market-based measures on transport, trade and climate change in Germany, Monkelbaan (2011) argued that a good carbon footprint approach is reducing carbon intensity without inhibiting compliance cost. The study supported fuel subsidy removal in order to relieve governmental fiscal burden during times of economic crisis and free up resources for spending on other priorities. Peters et al. (2009) revealed that it is possible to reduce carbon emisisons through international trade by $60 \%$ fossil fuel combustion and processed emissions from transport.

Likewise, Kim, Janic, \& Wee (2010) adopted linear programming-based algorithm to evaluate the trade-off between carbon dioxide emissions and logistics cost. The study revealed that trade-off curves exhibit a linear relationship which indicates that the rise in freight costs represent a prerequisite for carbon emisisons reduction. The study also established that an increase in the lower carbon emitting system's capacity would further reduce carbon emissions. In addition, Shapiro (2016) used a structural general equilibrium model and noted that gains from international trade were greater than the environmental cost of international trade. Zhang, Liu, \& Bae (2017) studied the effect of trade openness on carbon emissions in 10 newly industrialized countries. It was ascertained from the findings that in the long-run, there is correlation between international trade, carbon emissions, and real GDP, and trade activities reduces carbon emission through tecnological transfer. In China, Gozgor \& Can (2016) argued that energy consumption and trade openness positively influence carbon emissions, while export quality has an adverse effect on carbon emissions.

In Nigeria, Achike et al. (2012) examined the determinants of greenhouse gas emission and its impact on trade, climate change mitigation and adaptation of policies using Zellner's seemingly unrelated regression model. The study revealed that agricultural land expansion in all forms, farm technology based on increasing use of farm machineries and tractors, deforestation (forestry commercial activities), and the use of fossil fuel as a means of energy all contributed significantly to the level of carbon emissions in Nigeria. 
From the reviewed studies, it is noted that most of them do not have a unite conclusion due to the scope, methodology and the country focus. While some studies (Xie et al. 2017; Islam et al. 2012; Wang et al. 2016; Achike et al. 2012; Gozgor and Can, 2016; among others) argued a positive link between trade activities and emissions, studies of Perers et al. (2009); Cristea et al. (2013), Hasson and Masih (2017) argued a negative nexus on the phenomenon. This study however deviates by using the ARDL model to test the EKC curve and considering transportation activities as one of the factors that significantly contributes to increasing environmental degradation in Nigeria.

\section{METHODOLOGY AND DATA USED}

The study used annual secondary data sourced from the World Development Indicators (WDI), (2017). The data scope spans between 1984 and 2014. This is due to the data available on used energy and carbon emissions. The data used are as follows: Carbon emissions (Kt) proxy for environment, Energy use (kg oil equivalent per capita), transport services (\% of commercial services export), transport services (\% of commercial services import), trade (calculated as the ratio of import plus export to GDP), and GDP per capita (at current LCU). The data are analysed using E-views statiscal package, $9^{\text {th }}$ version. See Appendix 1 for the data used.

The study follows the model of existing studies such as Avetisyan et al. (2010); Cristea et al. (2013); Gozgor and Can (2016) and Zhang et al. (2017); on the validation of the EKC model. Our model also proposes that trade and transport services in the economy are important determinants of carbon emissions. Thus, the model is written as;

$$
C O_{2 t}=f\left(T R_{t}, G D P_{t}, E U_{t}, T R E_{t}, T R I_{t}\right)
$$

Taking the natural logarithm of equation (1), the function is re-specified as follows;

$$
I n C O_{2 t}=\alpha_{0}+\beta_{1} T R_{t}+\beta_{2} G D P_{t}+\beta_{3} \operatorname{InEU_{t}}+\beta_{4} T R E_{t}+\beta_{5} T R I_{t}+\varepsilon_{t}
$$

From equations (2), $I n C O_{2 t}$ implies log form of carbon emissions, $T R_{t}$ is trade captured as the ratio of trade to GDP, $\operatorname{InGDP}_{t}$ is $\log$ form of gross domestic product per capita, $\operatorname{InEU_{t}}$ is the log form of energy use in $\mathrm{Kg}$ oil equivalent per capita, $T R E_{t}$ is the log form of transport services as a percentage of commercial services export, $T R I_{t}$ is transport services as a percentage of commercial services import and $\varepsilon_{t}$ is the error term. All at time t. $\alpha_{0}$ is the model intercept, while $\beta_{1}-\beta_{5}$ are the coefficients of the parameters.

ARDL estimation technique is adopted to estimate the parameters of the model. The ARDL estimation model for the short-run and long-run relationship among the variables is specified as;

$$
\begin{aligned}
& \Delta \operatorname{InCO}_{2 t}=\vartheta_{0}+\sum_{q=1}^{n} \rho_{1} \Delta C O_{2 t-k}+\sum_{q=1}^{n} \rho_{2} \Delta T R_{t-k}+\sum_{q=1}^{n} \rho_{3} \operatorname{InGDP} P_{t-k}+\sum_{q=1}^{n} \rho_{4} \Delta \operatorname{InEU_{t-k}} \\
& +\sum_{q=1}^{n} \rho_{5} \Delta T R E_{t-k}+\sum_{q=1}^{n} \rho_{6} \Delta T R I_{t-k}+\beta_{1} C O_{2 t-1}+\beta_{2} T R_{t-1}+\beta_{3} G D P_{t-1} \\
& +\beta_{4} \operatorname{InEU_{t-1}}+\beta_{5} T R E_{t-1}+\beta_{6} T R I_{t-1}+\delta e c m_{t-1}+\varepsilon_{t}
\end{aligned}
$$


From equation (3), the $\Delta$ denotes the changes in the variables in the short-run, $n$ is the optimal lag length, $\varepsilon_{t}$ - error term at time. The parameters $\rho(i=1,2,3,4,5,6)$ are the corresponding long-run multiplier, and the parameters $\beta(1,2,3,4,5$ and 6$)$ are the short-run dynamic of the ARDL model. $\delta e c m$ is the parameter estimate of the error correction model.

\section{ANALYTICAL FRAMEWORK}

The study carried out a pre-estimation test to understand the behaviour of the data used in the study. The tests include; correlation test, descriptive statistics, unit root, and ARDL Bounds test.

\section{Correlation Test}

The correlation test shows that there is a weak negative insignificant correlation between trade and carbon emission. There is a very low positive insignificant correlation between import transport services and carbon emission. There is a strong positive significant correlation between export transport services, GDP, energy consumption and carbon emission. Since the correlation values are not up to 0.95 , this implies that multicollinearity problem is absence among the variables. Table 1 presents the result.

\begin{tabular}{|c|c|c|c|c|c|c|}
\hline & $\mathrm{InCO}_{2}$ & $T R$ & $T R I$ & $T R E$ & InGDP & InEU \\
\hline \multirow[t]{2}{*}{$\mathrm{InCO}_{2}$} & 1.0000 & & & & & \\
\hline & ----- & & & & & \\
\hline \multirow[t]{2}{*}{$T R$} & -0.1381 & 1.0000 & & & & \\
\hline & $(0.4666)$ & ---- & & & & \\
\hline \multirow[t]{2}{*}{ TRI } & 0.2506 & -0.5995 & 1.0000 & & & \\
\hline & $(0.1817)$ & $(0.0005)$ & ---- & & & \\
\hline \multirow[t]{2}{*}{$T R E$} & 0.7036 & -0.3591 & 0.4151 & 1.0000 & & \\
\hline & $(0.0000)$ & $(0.0513)$ & $(0.0226)$ & ----- & & \\
\hline \multirow[t]{2}{*}{ InGDP } & 0.5583 & 0.2711 & -0.2320 & 0.4639 & 1.0000 & \\
\hline & $(0.0013)$ & $(0.1473)$ & $(0.2174)$ & $(0.0098)$ & ---- & \\
\hline \multirow[t]{2}{*}{$\operatorname{InEU}$} & 0.7028 & 0.1067 & 0.1436 & 0.5853 & 0.8634 & 1.0000 \\
\hline & $(0.0000)$ & $(0.5748)$ & $(0.4490)$ & $(0.0007)$ & $(0.0000)$ & ----- \\
\hline
\end{tabular}

Note: The probability values are in parenthesis ( ) and ${ }^{*}$ denotes significance level at $1 \%$.

Table 1. Correlation Matrix Test

Source: Authors Computation (2018)

\section{Descriptive Statistics}

The result in table 2 shows that, on average, changes in environmental quality, trade activities, transportation activities, gross domestic products and energy use, range between $11.1 \%, 0.53 \%, 33.9 \%$, $10.1 \%$ and $6.6 \%$ respectively as a result of policy adjustments among other measures. Also, it can be 
deduced that the variables reaction to economic shocks are not outrageous or far from the expected equilibrium. The result also confirms that all the variables are normally distributed through the JarqueBera statistics which has a probability value greater than $10 \%$.

\begin{tabular}{lcccccc}
\hline & InCO$_{2}$ & TR & TRI & TRE & InGDP & InEU \\
\hline Mean & 11.10033 & 0.533829 & 33.278 & 35.89968 & 10.1386 & 6.577303 \\
Maximum & 11.57184 & 0.818128 & 53.21 & 93.35 & 13.14374 & 6.682488 \\
Minimum & 10.46879 & 0.236089 & 10 & 2.88 & 6.671149 & 6.509513 \\
Std. Dev. & 0.397434 & 0.158609 & 11.7779 & 29.08345 & 2.070137 & 0.049624 \\
Jarque-Bera & 3.666481 & 1.370994 & 1.601042 & 3.721383 & 1.982951 & 2.179895 \\
Probability & 0.159895 & 0.50384 & 0.449095 & 0.155565 & 0.371029 & 0.336234 \\
Observations & 31 & 31 & 31 & 31 & 31 & 31 \\
\hline
\end{tabular}

Table 2. Descriptive Statistics

Source: Authors Computation (2018)

\section{Unit Root Test}

The variables follow a unit root process and stationary after first differencing except energy use stationary at level using the Augmented Dickey Fuller (ADF) and Phillip Perron (PP) test. This implies that the empirical model is not appropriate for cointegration analysis. This facilitates the use of ARDL bounds test and ARDL estimation. The result is presented in table 3 below.

\begin{tabular}{|c|c|c|c|c|c|}
\hline & \multicolumn{2}{|c|}{ ADF } & \multicolumn{2}{|c|}{ PP } & \multirow[b]{2}{*}{ Order of Integration } \\
\hline Variables & Levels & First difference & Levels & First Difference & \\
\hline $\mathrm{InCO}_{2}$ & -1.987 & $-5.216^{\star}$ & -1.987 & $-5.216^{*}$ & $\mathrm{I}(1)$ \\
\hline $\operatorname{InEU}$ & $-3.246^{* *}$ & -4.734 & -2.436 & $-7.096^{*}$ & $\mathrm{I}(1)$ \\
\hline In $G D P$ & -1.798 & $-5.588^{\star}$ & -1.812 & $-7.390^{*}$ & $\mathrm{I}(1)$ \\
\hline$T R$ & -1.368 & $-8.654^{*}$ & -2.035 & $-26.570^{*}$ & $\mathrm{I}(1)$ \\
\hline$T R E$ & -2.611 & $-5.633^{\star}$ & -2.592 & $-5.657^{\star}$ & $\mathrm{I}(1)$ \\
\hline TRI & -1.898 & $-5.159^{\star}$ & -1.808 & $-12.004^{*}$ & $\mathrm{I}(1)$ \\
\hline
\end{tabular}

*, ${ }^{* *}$ implies $5 \%$ and $10 \%$ level of significance

Table 3. Unit Root Test Result

Source: Authors Computation (2018)

\section{Optimal Lag Test}

The study carried out an optimal lag test to select the appropriate lag length for the data used in the study. From the criteria available in the test, this study used the Akaike Information Criterion (AIC) result to select the optimal lag length. The result reveals an optimal lag length of 2 which is applied for this study (see table 4). 


\begin{tabular}{ccccccc}
\hline Lag & $\boldsymbol{L o g} L$ & $\boldsymbol{L R}$ & $\boldsymbol{F P E}$ & AIC & SC & HQ \\
\hline 0 & -172.18250 & NA & 0.03613 & 13.70634 & 13.99667 & 13.78995 \\
1 & -52.20761 & $175.3478^{*}$ & $6.14 \mathrm{e}-05^{*}$ & 7.24674 & $9.279049^{*}$ & $7.831971^{\star}$ \\
2 & -13.55360 & 38.65402 & 0.00008 & $\mathbf{7 . 0 4 2 5 8 4 ^ { * }}$ & 10.81687 & 8.12944 \\
\hline
\end{tabular}

* implies the selected lag length for each criterion

Table 4. Optimal Lag Length Results

Source: Authors computation (2018)

\section{ARDL Bounds Test}

The bounds test result is provided in table 5 . The result shows that there is a strong statistically significant cointegration relationship among the variables at $5 \%$ level. This is confirmed by the superior value of the F-statistics over the critical values of the lower and upper bounds class.

\begin{tabular}{ccc}
\hline Model for Estimation & F-Statistics & Lower-Upper bound at 5\% \\
\hline$F_{c o}\left(I n C O_{2 t} / I n T R_{t} / \operatorname{In} G D P_{t} / E U_{t} / T R I_{t} / T R E_{t}\right)$ & $\mathbf{4 . 7 8}^{\star}$ & $3.12-4.25$ \\
\hline
\end{tabular}

*implies cointegrating factors at $5 \%$ level of significance.

Table 5. ARDL Bounds Test

Source: Authors Computation (2018)

\section{ARDL Estimation}

Table 6 provides the short-run and the long-run estimate of the parameters. In the long-run, the result shows that the effect of trade is negative and elastic (-1.91). Import transport services are negative and elastic (0.079). Export transport services are positive and significant (0.010). GDP effect is negative and elastic (-2.45). Energy consumption is positive and elastic (13.22).

In the short-run, the model uses an optimal lag of 2 . This implies that carbon emission reacts to changes in the independent variables after 2years. The result shows that trade impact is positive and elastic (0.99). Import transport services are positive and elastic (0.011). Export transport services are positive and elastic (0.008). GDP and Energy use effect are positive and inelastic (0.29) and (2.49) respectively. The error correction model result shows that CO2 converges to equilibrium in the long-run by $0.74 \%$ at $5 \%$ significance level through the channels of trade, import and export transport services, GDP and energy use.

The stability and validity of the model is also tested using the serial correlation test, heteroscedasticity test and Recursive test. The result verified a serial correlation problem among the variables, but the absence of heteroscedasticity problem and assurance of the model stability at $5 \%$ significance level through the CUSUM and CUSUM squares test result retains the model (see table 6 and figure $1 \& 2$ ). 


\begin{tabular}{|c|c|c|}
\hline ARDL Long-run Estimate & Nigeria & $\operatorname{InCO} \mathrm{CO}_{2}$ \\
\hline \multirow[t]{5}{*}{ Selected Model: ARDL $(1,2,2,2,2,2)$} & $T R$ & $-1.914(0.0267)^{\star *}$ \\
\hline & $T R I$ & $-0.079(0.0028)^{*}$ \\
\hline & $T R E$ & $0.010(0.0476)^{\star *}$ \\
\hline & $\operatorname{InGDP}$ & $-2.452(0.0007)^{\star}$ \\
\hline & $\operatorname{InEU}$ & $13.217(0.0153)^{\star *}$ \\
\hline \multicolumn{3}{|l|}{ ARDL Short run Estimate } \\
\hline \multirow[t]{11}{*}{ Selected Model: ARDL $(1,2,2,2,2,2)$} & $\Delta T R_{t-1}$ & $0.127(0.7494)$ \\
\hline & $\Delta T R_{t-2}$ & $0.986(0.0486)^{\star \star}$ \\
\hline & $\Delta T R I_{t-1}$ & $-0.032(0.0147)$ \\
\hline & $\Delta T R I_{t-2}$ & $0.011(0.0793)^{\star * *}$ \\
\hline & $\Delta T R E_{t-1}$ & $0.014(0.0727)$ \\
\hline & $\Delta T R E_{t-2}$ & $0.008(0.0629)^{\star * \star}$ \\
\hline & $\Delta \operatorname{In} G D P_{t-1}$ & $-0.313(0.2095)$ \\
\hline & $\Delta \operatorname{InGDP} P_{t-2}$ & $0.286(0.4001)$ \\
\hline & $\Delta \operatorname{InE} U_{t-1}$ & $7.194(0.0088)$ \\
\hline & $\Delta \operatorname{In} E U_{t-2}$ & $2.486(0.3429)$ \\
\hline & $E C M_{t-1}$ & $-0.743(0.0062)^{*}$ \\
\hline $\mathrm{R} 2$ & Overall & 0.97 \\
\hline F-Statistic & Overall & $13.02[0.0004]$ \\
\hline Breusch-Godfrey Serial Correlation LM Test: & F-Stat & $6.617424[0.0304]$ \\
\hline Heteroskedasticity Test: Breusch-Pagan-Godfrey & F-Stat & $1.988655[0.1484]$ \\
\hline Stability Tests & CUSUM & Stable at $5 \%$ \\
\hline Stability Tests & CUSUM of Squares & Stable at $5 \%$ \\
\hline
\end{tabular}

Note: ${ }^{\star},{ }^{* *},{ }^{* *}$ implies significance level at $1 \%, 5 \%$, and $10 \%$ respectively, and the probability values are in parenthesis ( ) and [ ]

Table 6. ARDL Estimates and Diagnostic Test Results

Source: Authors' Computation (2018)

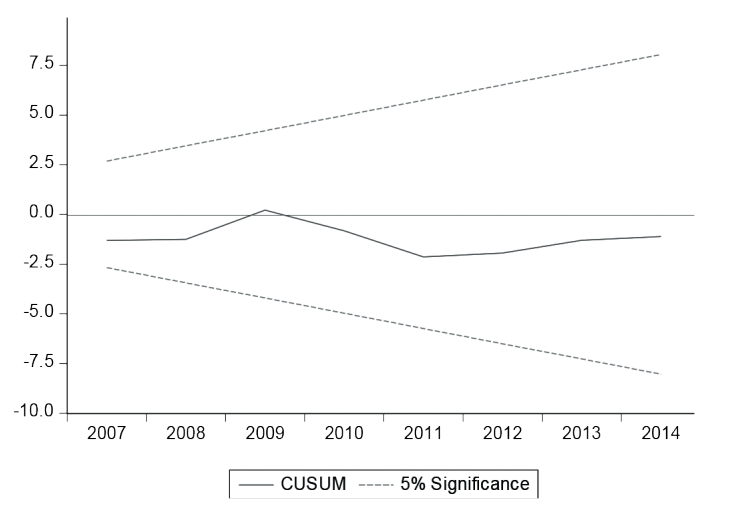

Figure 2. CUSUM Test

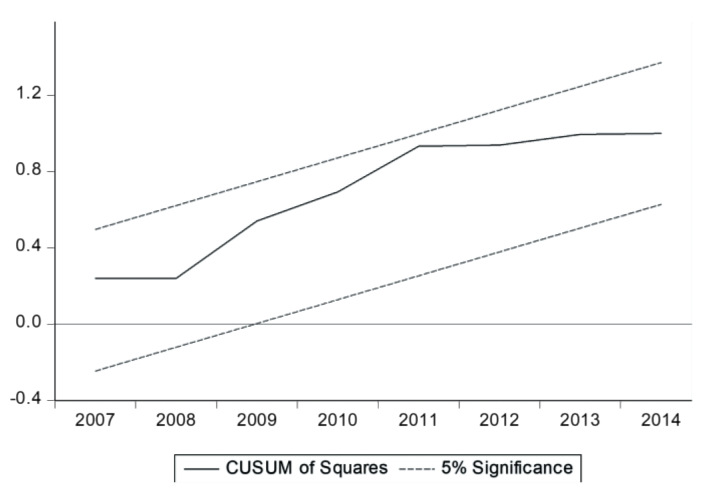

Figure 3. CUSUM of Square 


\section{Discussion of Findings}

From our empirical findings, firstly, the EKC model is validated in the context of Nigeria in the long-run. Similar to the study of Gozgor and Can (2016) for China, it was established that a positive linkage exists between growth per capita and carbon emissions in Nigeria. This implies that growth per head intensifies $\mathrm{CO} 2$ emissions in the long-run. Though, the variable shows a negative impact in the short-run after an adjustment of two years period, but in the long-run where increase in growth is needed by most developing countries to meet the increasing population needs, carbon emission increases and exposes the environment to more hazzards.

Second, energy consumption exerts same sign effect on carbon emissions. The result is in consonance with the study of Gozgor and Can (2016). The effect was significant in the short-run, and insignificant in the long-run. Given that Nigeria consumes more of fossil fuel product, it is not surprising that the result turns out to be similar to that of the economy of China. Adopting policies to reduce the consumption of fossil fuel product may not be the best, but considering alternative source of energy such as the renewable source, may be the reason for the insignificant effect in the long-run.

Third, trade in the short-run has a weak negative elastic impact on carbon emissions and in the long-run the positive impact is very strong and inelastic. This implies that trade activities at the earlier stage of the economy are tailored towards reducing carbon emissions, but as the activities expand, more technologies that consume more emission associated energy products are used. The findings also confirmed the proposition of the EKC model in the long-run for Nigrian economy on trade activities.

Fourth, import transport services in the short-run are elastic and negative, while they are positive and elastic in the long-run. This result shows that transportation of import goods in the economy significantly contributes to climate change experienced in recent years in the country through the emission they release.

Fifth, export transport services also exert a weak positive significant impact on $\mathrm{CO} 2$ emissions in Nigeria. This implies that the variable is a strong determinant of $\mathrm{CO} 2$ emissions increase in the economy through its activities.

Our findings also confirm the posibility of correcting the divergence of $\mathrm{CO} 2$ emissions by $74 \%$ back to long-run equilibrium if appropriate measures are taken.

\section{CONCLUSION AND RECOMMEDATION(S)}

The paper examines the relationship between environment, trade, energy consumption, export and import transport services and GDP per capita in Nigeria between 1984 and 2014. The study uses ARDL estimation technique to validate the relationship among the variables. It was observed that trade, import transport services and GDP per capita all have a negative and positive impact on CO2 emissions in the short-run and long-run respectively in Nigeria. Export transport services and energy consumption both show a positive relationship with $\mathrm{CO} 2$ emission in the short-run and long-run. The study concludes from the findings that trade, energy use, GDP and tranport services are important determinant of $\mathrm{CO} 2$ emissions in Nigeria and are capable of correcting emissions in the environment to fit the long-run equilibrium expectations if appropriate measures. Therefore, a major recommendation from the findings is that, energy consumption in the economy should be given utmost attention as it 
is an important variable to be used in all the sectors of the economy. This can be done by considering alternative energy sources (such as the renewables) that are enviromentally friendly, to reduce the positive impact of energy consumption in the short-run and long-run of the economy via its usage.

The work can be used as a basis for further research on the impact of trade, transport and the environment in other countries of the same level of development as Nigeria (African continent or other continents) and the findings can be compared with the circumstances in Nigeria. The study is however limited in terms of scope through data availabilty.

\section{REFERENCES}

Achike, A.I., Onoja, A.O., \& Agu, C. (2012). Green house gas emission determinants in Nigeria: implications for trade, climate change mitigation and adaptation policies. Retrieved from http://www.trapca.org/workingpapers/revised-version-of-paper-by-achike-onoja-and-Agu.pdf

Ahmad, N., \& Wyckoff, A. (2013). Carbon dioxide emissions embodied in international trade of goods. OECD Science, Technology and Industry Working Papers, 2003/15 1-66.

Ali, Z., Zaman, Z., \& Ali, M. (2015). The Effect of International Trade on Carbon Emissions: Evidence from Pakistan. Journal of Economics and Sustainable Development, 6(9), 289-299.http://www.iiste.org/Journals/ index.php/JEDS/article/viewFile/22639/23309

Athula, N. (2011). Does Trade Openness Promote Carbon Emissions? Empirical Evidence from Sri Lanka. The Empirical Economics Letters, 10(10), 972-986. Retrieved from http://hdl.handle.net/10072/42748

Avetisyan, M., Cristea, A., Hummels, D., \& Puzzello, L. (2010). Trade and the Greenhouse Gas Emissions from International Freight Transport. Retrieved from http://citeseerx.ist.psu.edu/viewdoc/download?doi=10.1.1.364 $.3822 \& \mathrm{rep}=\mathrm{rep} 1 \& \mathrm{type}=\mathrm{pdf}$

Cristea, A., Hummels, D., Puzzello, L., \& Avetisyan, M. (2013). Trade and the greenhouse gas emissions from international freight transport. Journal of Environmental Economics and Management, 65, 153-173. DOI:10.1016/j.jeem.2012.06.002

Feng, Z., Xue, J., \& Song, Y. (2013). Research on carbon emissions in China's export trade based on input-output model. Chinese Journal of Population Resources and Environment, 11(1), 1-9. DOI:10.1080/10042857.2013. 777202

Fenger, J. (2009). Air pollution in the last 50 years - From local to global. Atmospheric Environment, 43, 13-22. DOI:10.1016/j.atmosenv.2008.09.061

Fernandez-Amador, O., Francois, J. F., \& Tomberger, P. (2016). Carbon dioxide emissions and international trade at the turn of the millennium. Retrieved from https://www.wto.org/english/res_e/reser_e/gtdw_e/ wkshop16_e/francois_e.pdf

Gozgor, G., \& Can, M. (2016). Does export product quality matter for CO2 emissions? Environmental Science Pollution Resources, 1-10. DOI 10.1007/s11356-016-8070-6

Hasson, A., \& Masih, M. (2017). Energy consumption, trade openness, economic growth, carbon dioxide emissions and electricity consumption: evidence from South Africa based on ARDL. Retrieved from https://mpra. ub.uni-muenchen.de/id/eprint/79424

Islam, M. R., Cheng, Y., \& Rajib, M. S. (2012). International Trade and Carbon Emissions (CO2): The case of Bangladesh. Journal of Economics and Sustainable Development, 3 (5), 18-27.http://citeseerx.ist.psu.edu/ viewdoc/download?doi=10.1.1.855.7442\&rep=rep1\&type $=$ pdf

Keho, Y. (2016). Trade Openness and the Environment: A Time Series Study of ECOWAS Countries. Journal of Economics and Development Studies, 4(4), 61-69. DOI:10.15640/jeds.v4n4a6

Kim, N. S., Janic, M., \& Wee, B. v. (2010). Trade-Off Between Carbon Dioxide Emissions and Logistics Costs Based on Multiobjective Optimization. Transportation Research Record, 107-116. DOI: 10.3141/2139-13 
Kozul-Wright, R., \& Fortunato, P. (2012). International Trade and Carbon Emissions. European Journal of Development Research, 24(4), 509-529.

Li, J., Lu, Q., \& Fu, P. (2015). Carbon Footprint Management of Road Freight Transport under the Carbon Emission Trading Mechanism. Mathematical Problems in Engineering, 1-14.

Monkelbaan, J. (2011). Transport, Trade and Climate Change: Carbon Footprints, Fuel Subsidies and Marketbased Measures. International Centre for Trade and Sustainable Development, 1-60.

Peters, G.P., Marland, G., Hertwich, E. G., Saikku, L., Rautiainen, A., \& Kauppi, P. E. (2009). Trade, transport, and sinks extend the carbon dioxide responsibility of countries: An editorial essay. Climatic Change, 97, 379-388. DOI:10.1007/s10584-009-9606-2

Shapiro, J.S. (2016). Trade Costs, CO2, and the Environment. Retrieved from http://www.econ.yale.edu/ js2755/ Trade_CO2_Environment.pdf. 1-64.

Takarada, Y., Ogawa, T., \& Dong, W. (2014). Trade, Transportation, and the Environment: Welfare Effects of Emissions Reductions and International Emissions Trading. Retrieved from http://www.etsg.org/ETSG2014/ Papers/188.pdf.

Weber, C. L., Matthews, S. H., Corbett, J. J., \& Williams, E. D. (2007). Carbon Emissions Embodied in Importation, Transport and Retail of Electronics in the U.S. A Growing Global Issue. in: Proceedings of the 2007 IEEE Symposium on Electronics and the Environment, 174-179.

Zhang, S., Liu, X., \& Bae, J. (2017). Does trade openness affect CO2 emissions: evidence from ten newly industrialized countries? Environmental Science Pollution Resources. DOI:10.1007/s11356-017-9392-8

\section{APPENDIX 1 Data Used}

\begin{tabular}{ccccccc}
\hline Year & $\begin{array}{c}\text { Trade (cal- } \\
\text { culated as } \\
\text { the ratio of } \\
\text { import plus } \\
\text { export to } \\
\begin{array}{c}\text { GDP) proxy } \\
\text { as (TR) }\end{array}\end{array}$ & $\begin{array}{c}\text { GDP per cap- } \\
\text { ita (at current } \\
\text { LCU) proxy as } \\
\text { (GDP) }\end{array}$ & $\begin{array}{c}\text { Energy } \\
\text { use (kg oil } \\
\text { equivalent per } \\
\text { capita) proxy } \\
\text { as (EU) }\end{array}$ & $\begin{array}{c}\text { Transport } \\
\text { services }(\% \\
\text { of commer- } \\
\text { cial services } \\
\text { import) proxy } \\
\text { as (TRI) }\end{array}$ & $\begin{array}{c}\text { Transport } \\
\text { services (\% } \\
\text { of commer- } \\
\text { cial services } \\
\text { export) proxy } \\
\text { as (TRE) }\end{array}$ & $\begin{array}{c}\text { CO2 Emission } \\
\text { (Kt) proxy as } \\
\text { (CO) }\end{array}$ \\
\hline 1984 & 0.236088825 & 789.3021425 & 677.7652322 & 45.52 & 59.19 & 69625.329 \\
\hline 1985 & 0.259000637 & 879.5493062 & 682.8194438 & 44.71 & 73.97 & 69893.02 \\
\hline 1986 & 0.237167563 & 872.867951 & 671.4990085 & 38.93 & 27.13 & 73505.015 \\
\hline 1987 & 0.416466623 & 1270.270851 & 676.8560962 & 41.09 & 16.91 & 59343.061 \\
\hline 1988 & 0.353119785 & 1635.607191 & 678.8559452 & 53.21 & 36.3 & 70747.431 \\
\hline 1989 & 0.603917611 & 2460.585406 & 684.4482507 & 43.69 & 2.88 & 42441.858 \\
\hline 1990 & 0.530302209 & 2955.288186 & 697.192079 & 33.63 & 3.86 & 39196.563 \\
\hline 1991 & 0.648765987 & 3367.268305 & 712.2481627 & 45.19 & 11.26 & 42273.176 \\
\hline 1992 & 0.610309731 & 5542.175689 & 721.9703508 & 52.98 & 14.6 & 46614.904 \\
\hline 1993 & 0.581098489 & 6960.196381 & 715.4377996 & 31.81 & 17.17 & 45137.103 \\
\hline 1994 & 0.4230887 & 8974.894335 & 680.710066 & 25.3 & 13.63 & 35199.533 \\
\hline 1995 & 0.597678343 & 18595.84082 & 682.2695813 & 22.44 & 16.4 & 35841.258 \\
\hline 1996 & 0.576909942 & 25277.36571 & 693.778301 & 10 & 10.42 & 39665.939 \\
\hline
\end{tabular}




\begin{tabular}{|c|c|c|c|c|c|c|}
\hline 1997 & 0.76859991 & 25603.90787 & 699.6506998 & 15.86 & 11.55 & 42328.181 \\
\hline 1998 & 0.66173245 & 24198.89041 & 687.1179161 & 17.36 & 12.84 & 37869.109 \\
\hline 1999 & 0.558463914 & 27757.6646 & 694.1712967 & 19.85 & 12.03 & 40285.662 \\
\hline 2000 & 0.713805312 & 38555.41187 & 703.2447175 & 19.84 & 12.03 & 76057.247 \\
\hline 2001 & 0.818128491 & 39131.13426 & 720.047237 & 19.84 & 12.03 & 85734.46 \\
\hline 2002 & 0.633836372 & 55400.52357 & 724.6112534 & 19.84 & 12.03 & 93677.182 \\
\hline 2003 & 0.752189025 & 66245.95627 & 746.612206 & 22.46 & 10.4 & 101616.237 \\
\hline 2004 & 0.484481307 & 86219.73905 & 748.3413177 & & 20.17 & 104304.148 \\
\hline 2005 & 0.507483592 & 106055.7028 & 757.9586631 & 44.11 & 93.35 & 106067.975 \\
\hline 2006 & 0.646093139 & 131191.7073 & 744.5452271 & 27.36 & 88.82 & 98891.656 \\
\hline 2007 & 0.644629088 & 143022.3776 & 750.7831193 & 32.16 & 75.59 & 95055.974 \\
\hline 2008 & 0.649729738 & 164055.0215 & 752.8597869 & 30.6 & 65.94 & 96148.74 \\
\hline 2009 & 0.618028542 & 163443.6517 & 721.4533582 & 37.08 & 62.41 & 76735.642 \\
\hline 2010 & 0.426513849 & 349791.642 & 755.9891516 & 42.81 & 75.2 & 91517.319 \\
\hline 2011 & 0.527941049 & 391174.5039 & 778.4993881 & 35.92 & 68.6 & 95694.032 \\
\hline 2012 & 0.443801366 & 433955.8196 & 798.3031153 & 43.45 & 67.45 & 98502.954 \\
\hline 2013 & 0.3104886 & 471456.0508 & 779.8515426 & 42.55 & 57.36 & 98136.254 \\
\hline 2014 & 0.308851936 & 510805.4436 & 763.3913679 & 38.75 & 51.37 & 96280.752 \\
\hline
\end{tabular}

Source: WDI, 2017. 


\section{POVEZANOST TRGOVINE, TRANSPORTA I ŽIVOTNE SREDINE U NIGERIJI}

\section{Rezime:}

Ova studija istražuje odnos trgovine, transporta i životne sredine u Nigeriji. Glavni cilj studije jeste da uključi aktivnosti transporta i trgovina u EKC model, pošto autori smatraju da je transport važan faktor koji utiče degradaciju životne sredine u Nigeriji. Za potrebe ispitivanja korišćeni su godišnji podaci od 1984. do 2014. godine. Tehnika procene ARDL-a je usvojena u cilju analizea podataka. Rezultati pokazuju da sve varijable imaju pozitivnu značajnu korelaciju u odnosu na emisije ugljenika u Nigeriji, osim trgovine koja je bila negativna i beznačajna. Prema procenama ARDL-a, trgovina, usluge uvoza i BDP po glavi stanovnika pozitivno utiču na emisije $\mathrm{CO} 2$ dugoročno, dok u kratkom roku rezultati pokazuju da trgovina, BDP po glavi stanovnika, potrošnja energije i transportne usluge mogu da koriguju čak oko $74 \%$ odstupanja emisije ugljenika prema dostizanju dugotrajne ravnoteže. Na osnovu nalaza, zaključak predviđa da su potrošnja energije i trgovina glavni faktori koji doprinose emisiji ugljenika i treba posvetiti pažnju potrošnji energije uzimajući u obzir alternativne efikasne izvore energije kako bi se suzbila rastuća emisija u Nigeriji.

Ključne reči: trgovina, transport, $\mathrm{CO} 2$, ARDL. 